AKUNTABILITAS

Vol. VII No. 1, April 2014

P.ISSN: $1979-858 \mathrm{X}$

Halaman $56-68$

\title{
ANALISIS FAKTOR-FAKTOR YANG MEMPENGARUHI KINERJA MANAJERIAL
}

\author{
Taufik Hidayat \\ Universitas Trisakti Jakarta
}

\begin{abstract}
The purpose of this study is to examine the budget planning system, participation in drafting the budget, budget scheduling and budget goal clarity to managerial performance, as well as to search an internal control, and it may modernize the influence of budget planning system, participation in drafting the budgets, budget scheduling and budget goal clarity to managerial performance. This study is recognized as a causal research, and the location of study is Islamic state university Jakarta taking a sample of 69 respondents from the faculty and the rector. The test tool on hypothesis one is with t test used in evaluating the hypothesis partially, and $f$ test is used to search its influence simultaneously, while for searching to hypothesis two is to see the influence of moderating variable is as adopted to analyze the difference absolutely. Refers to the result of analysis is concluded that it partial system of budget planning, budget participation and budget goal clarity significant effect to managerial performance, while the budget schedule accuracy is not having an effect on managerial performance. It is also found that the internal control may not lead modernization any influence of the budget planning system, participation in drafting the budgets, budget scheduling and budget goal clarity to managerial performance.
\end{abstract}

Keywords: Budget, Internal Control, Managerial Performance

\begin{abstract}
ABSTRAK: Tujuan dari penelitian ini adalah untuk menguji sistem perencanaan anggaran, partisipasi dalam penyusunan anggaran, penjadwalan anggaran dan kejelasan sasaran anggaran terhadap kinerja manajerial, serta menguji pengawasan internal memoderasi pengaruh sistem perencanaan anggaran, partisipasi dalam penyusunan anggaran, penjadwalan anggaran dan sasaran anggaran terhadap kinerja manajerial. Penelitian ini sebagai penelitian kausal, dan lokasi penelitian adalah Universitas Islam Negeri Jakarta dengan mengambil sampel dari 69 responden dari fakultas dan rektorat. Uji alat pada hipotesis satu adalah dengan uji t digunakan dalam mengevaluasi hipotesis secara parsial, dan uji f digunakan untuk mencari pengaruhnya secara bersamaan, sedangkan untuk mencari hipotesis dua adalah untuk melihat pengaruh variabel moderasi untuk menganalisis perbedaan. Mengacu pada hasil analisis disimpulkan bahwa sistem parsial perencanaan anggaran, partisipasi anggaran dan kejelasan sasaran anggaran berpengaruh signifikan terhadap kinerja manajerial, sedangkan akurasi jadwal anggaran tidak berpengaruh terhadap kinerja manajerial. Hal ini juga ditemukan bahwa pengendalian internal tidak dapat menyebabkan moderasi pengaruh dari sistem perencanaan anggaran, partisipasi dalam penyusunan anggaran, penjadwalan anggaran dan sasaran anggaran kejelasan terhadap kinerja manajerial.
\end{abstract}

Kata kunci: Anggaran, Pengawasan Internal, Kinerja Manajerial

\footnotetext{
Draft pertama: 19 Januari 2014; Revisi: 23 Februari 2014; Diterima: 15 Maret 2014
}

"Penulis dapat dikontak melalui: taufikh_hdyt@yahoo.co.id 


\section{PENDAHULUAN}

Penggunaan anggaran merupakan konsep yang sering dipergunakan untuk melihat kinerja organisasi publik. Anggaran yang disusun harus dengan pendekatan kinerja. Penerapan anggaran berbasis kinerja pada instansi pemerintah di Indonesia dicanangkan melalui pemberlakuan UU No 17 tahun 2003 tentang Keuangan Negara dan diterapkan secara bertahap mulai tahun anggaran 2005.

Kinerja manajerial menunjukkan kemampuan dan prestasi seorang manajer dalam menjalankan organisasi untuk mewujudkan tujuan yang mengarah kepada ketercapaian pelayanan publik. Kepentingan kinerja manajerial dibutuhkan untuk menilai seberapa jauh lembaga/organisasi dapat menerapkan visi, misinya agar pelayanan publik dapat terwujud. Salah satu bentuk konsistensinya adalah perlu dilakukannya bentuk aktivitas yaitu melakukan penjaringan aspirasi masyarakat dan adanya kejelasan dalam partisipasi penyusunan anggaran yang terpadu sehingga dapat tercapai suatu sistem yang dapat mencegah atau meminimalisasi terjadinya kesalahan dalam mewujudkan good governance.

Universitas Islam Negeri (UIN) Syarif Hidayatullah Jakarta melakukan langkahlangkah strategis untuk meningkatkan kinerja organisasi melalui pembentukan BLU. Melalui Surat Keputusan Menteri Keuangan Nomor 42/PMK.05/2008 tanggal 26 Februari 2008 UIN Syarif Hidayatullah Jakarta berstatus BLU penuh dituntut melakukan perbaikan sistem administrasi dan keuangan yang merujuk pada Peraturan Pemerintah Nomor 23 Tahun 2005 yang menjelaskan bahwa Satuan Kerja (Satker) yang berfungsi sebagai pelayanan publik diizinkan untuk mengelola keuangan negara yang bersumber dari masyarakat dengan Pola Pengelolaan Keuangan Badan Layanan Umum (PK-BLU).

Kinerja manajer akan dikatakan efektif apabila tujuan organisasi yang telah tertuang dalam anggaran dapat dicapai. Partisipasi dapat meningkatkan kinerja karena partisipasi memungkinkan bawahan mengkomunikasikan apa yang mereka butuhkan kepada atasannya dan partisipasi dapat memungkinkan bawahan untuk memilih tindakan yang dapat membangun komitmen dan dianggap sebagai tanggung jawab atas apa yang telah dipilih. Oleh karena itu, partisipasi dalam hal ini diharapkan dapat meningkatkan kinerja manajerial secara keseluruhan.

Kejelasan sasaran anggaran mencerminkan sejauh mana tujuan anggaran ditetapkan secara spesifik dan jelas sehingga dapat dipahami oleh orang yang bertanggung jawab dalam pencapaiannya. Apabila sasaran tidak disebutkan secara spesifik akan menyebabkan kebingungan yang akan berdampak buruk terhadap kinerja.

\section{KERANGKA TEORI DAN PENGEMBANGAN HIPOTESIS Anggaran}

Nafarin (2004) menyebutkan anggaran adalah: "suatu rencana keuangan periodic yang disusun berdasarkan program yang disahkan, dimana perencanaan merupakan tindakan yang dibuat berdasarkan fakta dan asumsi mengenai gambaran kegiatan yang akan dilakukan pada waktu yang akan datang dalam mencapai tujuan yang diinginkan".

Penulis lain mendefinisikan, "anggaran adalah suatu rencana terinci yang dinyatakan secara formal dalam ukuran kuantitatif, biasanya dalam satuan uang (perencanaan keuangan) untuk menunjukkan perolehan dan penggunaan sumber-sumber suatu organisasi" (Yuwono, 2005). Sumber lain menyebutkan, "anggaran dapat juga dinyatakan sebagai pernyataan mengenai estimasi yang hendak dicapai selama periode waktu tertentu dalam ukuran finansial" (Nordiawan, 2006).

Penganggaran merupakan proses penerjemahan rencana aktivitas ke dalam rencana keuangan. Dalam sebuah organisasi besar, penganggaran boleh jadi merupakan proses yang terus menerus. Bagi organisasi yang besar dan telah matang (mature) dengan tingkat operasional yang relatif stabil dalam jangka panjang, anggaran merupakan dokumen formal 
yang sangat terperinci. Untuk itu perlu waktu yang lama dalam menyiapkan suatu anggaran agar tersedia tepat di periode tahun berikutnya dan disetujui semua pihak.

Penetapan penganggaran BLU, dimulai dari penyusunan suatu rancangan rencana kerja tahunan yang dikonsolidasikan dengan rancangan rencana kerja kementerian negara/lembaga. Setelah kementerian negara/lembaga memperoleh pagu indikatif, yang kemudian dipecah ke dalam suatu kegiatan, salah satunya pagu indikatif untuk BLU di bawah binaannya. Setelah menerima pagu indikatif, BLU yang bersangkutan rancangan rencana kerja. Di lingkungan intern BLU, unit-unit di bawah BLU menyusun rancangan rencana kerjanya (Bottom-up). Rancangan rencana kerja yang telah disusun suatu BLU disampaikan kepada kementerian negara/lembaga binaannya untuk diintegrasikan. BLU diharapkan dapat mendampingi kementerian negara/lembaga dalam pembahasan rencana kerja di DPR/DPRD.

\section{Kinerja Manajerial}

Kinerja merupakan suatu prestasi atau tingkat keberhasilan yang dicapai oleh individu atau suatu organisasi dalam melaksanakan pada suatu periode tertentu. Menurut Stoner (1986) kinerja (performance) merupakan kuantitas dan kualitas pekerjaan yang diselesaikan oleh individu, kelompok atau organisasi. Pada sector pemerintahan, kinerja dapat diartikan sebagai suatu prestasi yang dicapai oleh pegawai pemerintah atau instansi pemerintah dalam melaksanakan pelayanan kepada masyarakat dalam suatu periode.

Kinerja manajerial merupakan kinerja para individu dalam kegiatan-kegiatan manajerial, seperti: perencanaan, investigasi, koordinasi, evaluasi, pengawasan, pengaturan staf, negosiasi dan perwakilan (Mahoney, 1963). Kinerja sebagai hasil kerja yang dapat dicapai oleh seseorang atau sekolompok orang dalam suatu organisasi sesuai dengan wewenang dan tanggung jawab masing-masing dalam upaya mencapai tujuan organisasi yang bersangkutan secara legal, tidak melanggar hukum dan sesuai dengan moral dan etika (Prawirosentono, 1999).

Kinerja merupakan faktor penting yang digunakan untuk mengukur efektitas dan efisiensi organisasi. Menurut Supomo dan Indriantoro (1998) bahwa: "Kinerja manajerial adalah kinerja para individu anggota organisasi dalam kegiatan-kegiatan manajerial, antara lain: perencanaan, koordinasi, supervisi, staffing, negosiasi, dan representasi”. Bagi organisasi itu sendiri kinerja manajerial dapat menjadi tolak ukur sejauh mana manajer melaksakanan fungsi manajemen.

\section{Pengawasan Internal}

Pengawasan merupakan tahap integral dengan keseluruhan tahap pada penyusunan dan pelaporan APBN. Pengawasan diperlukan pada setiap tahap bukan hanya pada tahap evaluasi saja (Mardiasmo, 2001) Pengawasan yang dilakukan oleh pelaksanaan APBN dan Pertanggung jawaban APBN. Dengan adanya pengawasan di setiap tahapan pengelolaan keuangan Pusat, maka diharapkan proses pengelolaan keuangan Pusat terutama dalam proses penyusunan anggaran akan memperbesar pengaruhnya terhadap kinerja manajerial Satuan Kerja.

Dalam rangka meningkatkan kinerja, transparansi, dan akuntabilitas pengelolaan keuangan BLU, Pimpinan BLU selaku penanggung jawab penyelenggaraan sistem pengendalian intern di instansi BLU yang dipimpinnya atas persetujuan menteri/pemerintah daerah selaku Pembina teknis dan keuangan, membentuk Satuan Pengawasan Intern (SPI) yang tugasnya membantu direksi BLU dalam mengindentifikasi permasalahan operasional dan keuangan serta menilai kinerja manajemen, menilai pengendalian, pengelolaan dan pelaksanaan BLU dan memberikan saran-saran perbaikan. Satuan Pengawasan Intern dimaksud dipimpin oleh seorang kepala yang bertanggung jawab langsung kepada Pimpinan BLU. Pimpinan BLU wajib memperhatikan dan segera 
mengambil langkahlangkah yang diperlukan atas segala sesuatu yang dikemukakan dalam setiap laporan hasil pemeriksaan yang dibuat oleh Satuan Pengawasan Intern.

\section{Kerangka Pemikiran Teoritis}

Berdasarkan tinjauan pustaka dan permasalahan yang akan diteliti, maka model kerangka teoritis yang dikembangkan dalam penelitian ini:

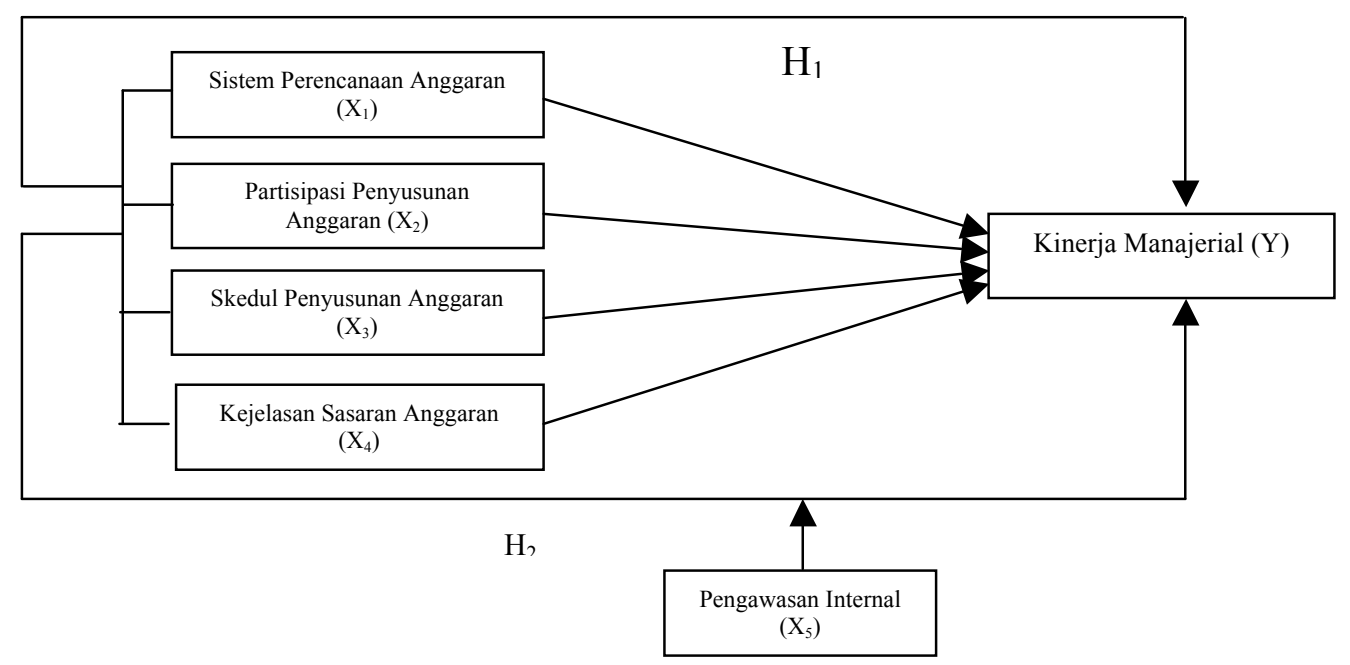

Gambar 1. Kerangka Teoritis

\section{Pengembangan Hipotesis}

Dari kerangka konseptual di atas, dapat diuraikan bahwa Sistem Perencanaan Anggaran, partisipasi dalam penyusunan anggaran, Skedul Penyusunan Anggaran dan kejelasan sasaran anggaran mempengaruhi kinerja manajerial Satuan Kerja, dengan kata lain Sistem Perencanaan Anggaran, partisipasi dalam penyusunan anggaran, Skedul Penyusunan Anggaran dan kejelasan sasaran anggaran yang merupakan variabel independen akan mempengaruhi kinerja manajerial Satuan Kerja sebagai variabel independen.

Berdasarkan uraian sebelumnya, maka hipotesis dalam penelitian ini adalah sebagai berikut:

$\mathbf{H}_{\mathbf{1}}$ : Sistem Perencanaan Anggaran, partisipasi dalam penyusunan anggaran, Skedul Penyusunan Anggaran dan kejelasan sasaran anggaran berpengaruh signifikan terhadap kinerja manajerial satuan kerja.

$\mathbf{H}_{2}$ : Pengawasan internal memoderasi Pengaruh Sistem Perencanaan Anggaran, partisipasi dalam penyusunan anggaran, Skedul Penyusunan Anggaran dan kejelasan sasaran anggaran terhadap kinerja manajerial satuan kerja

\section{METODE PENELITIAN}

\section{Pengumpulan Data}

Pengumpulan data pada penelitian ini dilakukan dengan data primer yaitu penelitian lapangan melalui pembagian kuesioner kepada subjek penelitian yang dituju. Kuesioner ini dibagikan kepada para pimpinan, pejabat pengelola keuangan dan satuan pemeriksa intern (SPI) di Lingkungan UIN Syarif Hidayatullah Jakarta.

Adapun kriteria responden yang digunakan adalah para pimpinan, pejabat pengelola keuangan, bendahara dan Satuan Pemeriksa Intern (SPI) di lingkungan UIN Syarif Hidayatullah Jakarta. Ukuran sampel ditetapkan dengan cara Non Statistical 
Sampling, di mana besarnya sampel tanpa menggunakan rumus perhitungan penentuan besarnya sampel. Instrumen penelitian berupa kuesioner yang berhubungan dengan indikator yaitu kuesioner Kinerja manajerial Satuan Kerja, Kuesioner Sistem Perencanaan Anggaran, kuesioner partisipasi penyusunan anggaran, kuesioner kejelasan sasaran anggaran, dan kuesioner pengawasan internal yang menghasilkan data interval.

\section{Definisi Operasional dan Pengukuran Variabel}

Ada enam variabel yang digunakan dalam penelitian ini yaitu: (1) Kinerja manajerial Satuan Kerja, (2) Sistem Perencanaan Anggaran, (3) partisipasi dalam penyusunan anggaran, (4) Skedul Penyusunan anggaran, (5) Kejelasan Sasaran Anggaran dan (6) pengawasan internal. Definisi operasional dapat dijelaskan sebagai berikut:

Kinerja manajerial (Y) didefinisikan sebagai hasil dari proses aktivitas manajerial yang efektif mulai dari proses perencanaan dan penganggaran, penatausahaan, pelaporan, pertanggungjawaban dan pengawasan. Pengukuran variabel ini menggunakan instrumen kuesioner dengan skala interval dan menunjukkan tingkat kinerja manajerial. Kuesioner ini diadaptasi dari Bangun (2009) dengan mempertimbangkan fungsi-fungsi manajerial yang terdapat di Pemerintah daerah sesuai dengan Peraturan Menteri Dalam Negeri Nomor 13 Tahun 2006.

Sistem perencanaan anggaran $\left(\mathrm{X}_{1}\right)$ dapat dikatakan baik apabila direncanakan sesuai dengan sasaran/target kinerja (outcome) sehingga dapat menghasilkan efisien dan efektifitas pelaksanaan setiap program dan kegiatan yang direncakanakan sesuai dengan teori yang dikemukakan Mardiasmo (2006) indikator utama sebuah perencanaan anggaran harus memiliki:

Target Kinerja (Targetting Point) adalah ukuran Prestasi Kerja secara kuantitatif dan dapat diukur dan dibandingkan secara jelas dari keadaan semula dengan mempertimbangkan efisiensi dan efektifitas pelaksanaan setiap program dan kegiatan.

Hasil (Outcome) adalah ukuran yang mencerminkan berfungsinya keluaran dari kegiatan-kegiatan dalam satu program.

Pengukuran variabel ini menggunakan instrumen kuesioner dengan skala interval. Kuesioner ini di adaptasi dari penelitian Hamid (2011).

Partisipasi dalam penyusunan anggaran $\left(\mathrm{X}_{2}\right)$ adalah partisipasi manajerial satuan kerja dalam proses penganggaran, seperti program dan kegiatan yang akan dilaksanakan, keikutsertaan dalam menentukan target dan anggaran dan sebagainya. Untuk mengukur variabel ini digunakan skala interval dan menunjukkan tingkat partisipasi aparat dalam penyusunan anggaran. Kuesioner ini merupakan adaptasi yang dikembangkan oleh (Bangun, 2009) dengan mempertimbangkan fungsi-fungsi menejerial yang terdapat di Pemerintahan Daerah sesuai dengan Permendagri No. 13 tahun 2006 dan sebelum dilakukan pengujian statistik lebih lanjut akan dilakukan uji pra test.

Ketepatan skedul penyusunan anggaran $\left(\mathrm{X}_{3}\right)$ merupakan tingkat kesesuaian waktu penyusunan anggaran yang telah laksanakan dibandingkan dengan kalender penyusunan anggaran yang telah ditetapkan. Pengukuran variabel ini menggunakan instrumen kuesioner dengan skala 5 point untuk menunjukkan ketepatan skedul anggaran yaitu memberikan nilai pada setiap jarak waktu yang terjadi dengan ketentuan yang seharusnya. Ketepatan skedul Penyusunan Anggaran telah ditetapkan dalam standar operasional prosedur penyusunan anggaran yang ditetapkan okeh Rektor UIN Syarif Hidayatullah Jakarta. Kuesioner ini didesain dengan mengadaptasi dari penelitian Syafrial (2009) yang kemudian disesuaikan dengan standar operasional prosedur yang ditetapkan oleh satua kerja UIN Syarif Hidayatullah Jakarta. Sebelum dilakukan pengujian statistik lebih lanjut dilakukan uji pra test.

Kejelasan sasaran anggaran $\left(\mathrm{X}_{4}\right)$ adalah kondisi kinerja yang akan dicapai yang tertuang dalam rencana kerja anggaran satuan kerja. Variabel ini diukur dengan 
menggunakan skala interval 5 point dan menunjukkan kejelasan sasaran anggaran dalam penyusunan anggaran. Kuesioner ini diadaptasi dari penelitian bangun (2009).

Pengawasan Internal $\left(\mathrm{X}_{5}\right)$ adalah pengawasan yang dilakukan oleh Inspektorat Jenderal Kementerian dan satuan pemeriksan intern (SPI) dalam lingkungan satuan kerja, dalam hal ini dibatasi pada proses kegiatan yang ditujukan untuk menjamin agar pemerintah menjalankan rencana yang telah tertuang dalam RKA K/L secara efisien dan efektif juga untuk menjamin agar penyusunan anggaran telah mempertimbangkan unsure efesiensi, efektifitas, dan ekonomis. Variabel ini diadaptasi dari penelitian bangun (2005) sesuai sesuai Permendagri Nomor 23 tahun 2007, kemudian diadaptasi dengan keadaan dan tempat penelitian. variabel ini diukur dengan skala interval 5 point.

\section{Teknik Analisa Data}

Model yang digunakan dalam penelitian ini menggunakan model regresi linier berganda dan analisis regresi bertingkat dijabarkan di bawah ini:

$$
\begin{aligned}
\text { Model 1: } Y= & \beta_{1}+\beta_{1} X_{1}+\beta_{2} X_{2}+\beta_{3} X_{3}+\beta_{4} X_{4}+e \\
\text { Model 2: } Y= & \beta_{1}+\beta_{1} X_{1}+\beta_{2} X_{2}+\beta_{3} X_{3}+\beta_{4} X_{4}+\beta_{5} X_{5}+\beta_{3} X_{1}-X_{5}+\beta_{4} X_{2}-X_{5}+ \\
& \beta_{5}\left|X_{3}-X_{5}+\beta_{6}\right| X_{4}-X_{5}+e
\end{aligned}
$$

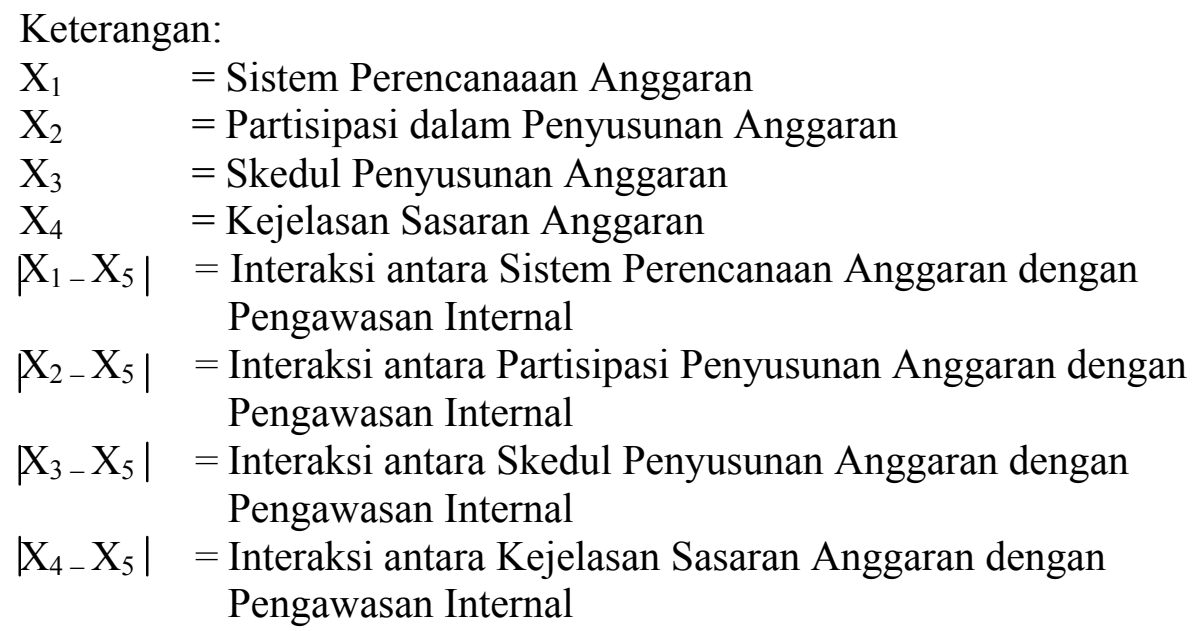

\section{Uji Kualitas Data}

\section{Uji Validitas}

Uji validitas dimaksudkan untuk menilai sejauh mana suatu alat ukur diyakini dapat dipakai sebagai alat untuk mengukur item-item pertanyaan/pernyataan kuesioner dalam penelitian. Teknik yang digunakan untuk mengukur validitas pertanyaan/ pernyataan kuesioner adalah Korelasi Product Moment dari Karl Pearson dengan ketentuan: jika $r$ hitung lebih besar dari $\mathrm{r}$ tabel, maka skor butir pertanyaan/ pernyataan kuesioner valid tetapi sebaliknya jika $r$ hitung lebih kecil dari $r$ tabel, maka skor butir pertanyaan/pernyataan kuesioner tidak valid. Selain itu untuk kuesioner yang di disain sendiri akan dilakukan uji pra test sebelum dilakukan pengujian statistik lebih lanjut.

\section{Uji Reliabilitas}

Pengujian reliabilitas dilakukan untuk menguji kestabilan dan konsistensi instrument dalam mengukur konsep. Selain itu, pengujian reliabilitas dilakukan untuk membantu menetapkan kesesuaian pengukur. Pengujian reliabilitas setiap variabel dilakukan dengan teknik Cronchbach Alpha. Teknik ini merupakan pengujian yang paling umum dilakukan pada pengujian reliabilitas inter item, yaitu menggunakan item-item 
pertanyaan yang berskala multipoint (Sekaran, 1992). Suatu instrument dinyatakan reliabel jika memiliki nilai Cronchbach Alpha lebih besar dari o,6 (Nunnaly, 1967) dalam Ghozali (2005).

\section{Pengujian Asumsi Klasik}

Sebelum dilakukan pengujian hipotesis dengan menggunakan analisis regresi berganda, maka diperlukan pengujian asumsi klasik yang meliputi pengujian normalitas, mulikolinearitas, hetoroskedastisitas.

\section{Pengujian Hipotesis}

Pengujian hipotesis pertama yaitu untuk melihat apakah ada pengaruh sistem perencanaan anggaran partisipasi dalam penyusunan anggaran, kejelasan sasaran anggaran, dan struktur desentralisasi terhadap kinerja manajerial aatuan kerja daerah menggunakan analisa regresi berganda. Untuk menguji hipotesis yang diajukan dilakukan dengan melihat rata-rata nilai variabel yang dipakai. Kuesioner diarahkan untuk jawaban positif atau negatif.

Interval jawaban terdiri dari 1 sampai dengan 5, dan jawaban point 4 dan point 5 merupakan jawaban positif karena jawaban point 4 adalah setuju dan point 5 adalah sangat setuju. Untuk menguji hipotesis 1 mengenai pengaruh partisipasi dalam penyusunan anggaran, kejelasan sasaran anggaran, dan struktur desentralisasi terhadap kinerja manajerial secara simultan dan parsial digunakan pengujian hipotesis secara parsial dengan uji t, dan secara simultan dengan uji F.

Pengujian hipotesis 2 yaitu untuk melihat pengaruh interaksi antara moderating variabel dengan masing-masing variabel independen terhadap kinerja manajerial Satuan Kerja digunakan analisa selisih mutlak.

\section{HASIL DAN PEMBAHASAN}

\section{Statistik Deskriptif}

Jumlah kuesioner yang disebarkan sebanyak 105 kuesioner yang dikirim ke 11 fakultas, sekolah pascasarjana dan rektorat. Dari jumlah tersebut, tingkat pengembaliannya hanya $65 \%$ atau sebayak 69 kuesioner, sedangkan sisanya 31\% atau sebanyak 36 kuesioner tidak kembali di karenakan kesibukan para pimpinan. Dengan demikian, jumlah kuesioner yang dapat digunakan sebagai data penelitian untuk dianalisis lebih lanjut adalah sebanyak 69 kuesioner.

Adapun data pengembalian kuesioner ditampilkan dalam tabel berikut ini:

Tabel 1. Pengembalian Kuesioner

\begin{tabular}{|l|c|c|}
\hline \multicolumn{1}{|c|}{ Keterangan } & Jumlah & Persentase \\
\hline Kuesioner yang kirim & 105 & $100 \%$ \\
\hline Kuesioner tidak kembali & 36 & $35 \%$ \\
\hline Kuesioner kembali dan diolah & 69 & $65 \%$ \\
\hline
\end{tabular}

Sumber: Kuesioner kembali

\section{Hasil Uji Kualitas Data}

Uji Validitas

Hasil uji validitas terlihat bahwa instrumen sistem perencanaan anggaran, partisipasi penyusunan anggaran, skedul penyusunan anggaran, kejelasan sasaran anggaran, pengawasan internal dan kinerja manajerial menunjukan hasil yang signifikan, karena tingkat signifikansinya di bawah o,05 dengan menggunakan pearson correlation two tailed. 
Jadi dapat disimpulkan bahwa semua pertanyaan yang diajukan kepada responden dinyatakan valid.

\section{Uji Reliabilitas}

Pengujian reliabilitas setiap variabel dilakukan dengan teknik Cronchbach Alpha. Hasil uji reliabilitas terlihat bahwa instrumen sistem perencanaan anggaran memiliki koefisien korelasi > 0.600 , yaitu 0,785 menunjukkan hasil yang signifikan. Instrumen partisipasi penyusunan anggaran memiliki koefisien korelasi $>$ o,6oo yaitu 0,795 menunjukan hasil yang signifikan. Instrumen skedul penyusunan anggaran memiliki koefisien korelasi > o,6oo yaitu o,818 menunjukan hasil yang signifikan. Instrumen kejelasan sasaran anggaran memiliki koefisien korelasi $>0,600$ yaitu o,831 menunjukan hasil yang signifikan. Instrumen pengawasan internal memiliki koefisien korelasi > o,6oo yaitu o,88o menunjukan hasil yang signifikan. Sedangkan instrumen kinerja manajerial memiliki koefisien korelasi > o,60o yaitu o,628 menunjukan hasil yang signifikan. Jadi dapat disimpulkan bahwa semua pertanyaan yang diajukan kepada responden dinyatakan reliabel.

\section{Pengujian Hipotesis I}

Pengujian hipotesis dilakukan dengan menggunakan analisis regresi linear berganda dengan tingkat signifikansi $\alpha=0,05$. Setelah dilakukan pengujian asumsi klasik dan diperoleh kesimpulan bahwa model sudah dapat digunakan untuk melakukan pengujian analisa regresi berganda, maka langkah selanjutnya melakukan pengujian hipotesis. Hipotesis yang akan diuji adalah sistem perencanaan anggaran, partisipasi dalam penyusunan anggaran, skedul penyusunan anggaran dan kejelasan sasaran anggaran berpengaruh terhadap kinerja manajerial satuan kerja. Ringkasan hasil pengujian hipotesis dapat dilihat pada tabel berikut ini.

Tabel 2. Uji Koefisien Determinasi

\begin{tabular}{|l|l|r|r|r|r|}
\hline Model & \multicolumn{1}{|c|}{ Model Summary } \\
\hline 1 &, $699^{\text {a }}$ & R Square & $\begin{array}{c}\text { Adjusted R } \\
\text { Square }\end{array}$ & $\begin{array}{c}\text { Std. Error of } \\
\text { the Estimate }\end{array}$ & $\begin{array}{c}\text { Durbin- } \\
\text { Watson }\end{array}$ \\
\hline
\end{tabular}

a. Predictors: (Constant), SA, PPA, SPA, KSA

b. Dependent Variable: KM

Berdasarkan hasil pengujian, diperoleh nilai R sebesar o,699, hal ini menunjukkan bahwa variabel sistem perencanaan anggaran, partisipasi dalam penyusunan anggaran, skedul penyusunan anggaran dan kejelasan sasaran anggaran mempunyai hubungan yang sangat kuat dengan kinerja manajerial. Nilai adjusted $R^{2}$ sebesar o,457 mempunyai arti bahwa variable dependen mampu dijelaskan oleh variabel independen sebesar $45,7 \%$. Dengan kata lain $45,7 \%$ perubahan dalam kinerja manajerial satuan kerja mampu dijelaskan variabel sistem perencanaan anggaran, partisipasi dalam penyusunan anggaran, skedul penyusunan anggaran dan kejelasan sasaran anggaran. Sebagian besar 54,3\% dijelaskan oleh faktor lain yang tidak diikutkan dalam penelitian ini. Faktor lain yang tidak diikutkan seperti motivasi, budaya organisasi, komitmen organisasi dan gaya kepemimpinan. 
Tabel 3. Uji F atau ANOVA untuk Kinerja Manajerial ANOVA $^{\mathrm{b}}$

\begin{tabular}{|l|r|r|r|r|r|}
\hline \multicolumn{1}{|l|}{ Model } & Sum of Squares & Df & Mean Square & F & Sig. \\
\hline $1 \quad$ Regression & 145,256 & 4 & 36,314 & 15,300 & ,0oo $^{\text {a }}$ \\
Residual & 151,903 & 64 & 2,373 & & \\
\multicolumn{1}{|l|}{ Total } & 297,159 & 68 & & & \\
\hline
\end{tabular}

a. Predictors: (Constant), SA, PPA, SPA, KSA

b. Dependent Variable: KM

Dari table 3 hasil uji ANOVA atau F test, dapat dijelaskan bahwa F hitung diperoleh angka 15,300 dengan tingkat signifikan o,ooo. Karena probabilitas o,ooo lebih kecil dari 0,05, maka hasil dari model regresi menunjukkan bahwa secara keseluruhan ada pengaruh sistem perencanaan anggaran, partisipasi dalam penyusunan anggaran, kejelasan sasaran anggaran dan skedul penyusunan anggaran terhadap kinerja manajerial satuan kerja. Dari uraian tersebut, maka dapat diambil kesimpulan bahwa sistem perencanaan anggaran, partisipasi dalam penyusunan anggaran, kejelasan sasaran anggaran dan skedul penyusunan anggaran berpengaruh secara signifikan terhadap kinerja manajerial. Dengan kata lain model ini fit digunakan dalam penelitian.

Tabel 4. Uji t untuk Kinerja Manajerial Coefficients $^{\mathrm{a}}$

\begin{tabular}{|c|c|c|c|c|c|}
\hline \multirow[b]{2}{*}{ Model } & \multicolumn{2}{|c|}{$\begin{array}{c}\text { Unstandardized } \\
\text { Coefficients } \\
\end{array}$} & \multirow{2}{*}{$\begin{array}{c}\text { Standardized } \\
\text { Coefficients } \\
\text { Beta }\end{array}$} & \multirow[t]{2}{*}{$\mathrm{t}$} & \multirow[t]{2}{*}{ Sig. } \\
\hline & B & $\begin{array}{l}\text { Std. } \\
\text { Error }\end{array}$ & & & \\
\hline $1 \quad$ (Constant) & 7,946 & 2,277 & & 3,489 & ,001 \\
\hline $\begin{array}{l}\text { Sistem Perencanaan } \\
\text { Anggaran }\end{array}$ & ,248 & 106 & ,289 & 2,352 & ,022 \\
\hline $\begin{array}{l}\text { Partisipasi Penyusunan } \\
\text { Anggaran }\end{array}$ & ,170 & ,o84 & 199 & 2,017 & , 048 \\
\hline $\begin{array}{l}\text { Kejelasan Sasaran } \\
\text { Anggaran }\end{array}$ & ,265 & ,093 &, 365 & 2,851 & ,oo6 \\
\hline $\begin{array}{l}\text { Skedul Penyusunan } \\
\text { Anggaran }\end{array}$ &,- 036 & , o74 &,- 044 &,- 480 & ,633 \\
\hline
\end{tabular}

a. Dependent Variable: KM

Berdasarkan hasil uji hipotesis yang telah dilakukan maka model penelitian adalah sebagai berikut:

$$
Y=\alpha+b_{1} X_{1}+b_{2} X_{2}+b_{3} X_{3}+b_{4} X_{4}
$$

Dari persamaan di atas, dapat dijelaskan bahwa koefisien dari variabel sistem perencanaan anggaran $(2,352)$, partisipasi dalam penyusunan anggaran $(2,017)$ dan kejelasan sasaran anggaran $(2,851)$ menunjukkan angka positif. Berarti bahwa hubungan antara variabel bahwa sistem perencanaan anggaran, partisipasi dalam penyusunan anggaran dan kejelasan sasaran anggaran adalah semakin tinggi variabel sistem perencanaan anggaran, partisipasi dalam penyusunan anggaran dan kejelasan sasaran anggaran maka semakin 
tinggi kinerja manajerial. Sedangkan variabel skedul penyusunan anggaran menunjukkan angka yang negative $(-, 480)$ Berarti semakin tinggi variabel skedul penyusunan anggaran, maka semakin rendah kinerja manajerial.

Untuk melihat pengaruh masing-masing variabel independen secara parsial terhadap kinerja manajerial, maka dapat dilihat dari nilai signifikansi t hitung tersebut. Jika nilai signifikansi dari t hitung tersebut lebih kecil dari o.05, maka dapat dinyatakan bahwa ada pengaruh variabel tersebut terhadap kinerja manajerial. Berdasarkan hasil pengujian data, maka dapat dinyatakan bahwa variabel skedul penyusunan anggaran tidak mempunyai pengaruh secara signifikan terhadap kinerja manajerial. Sedangkan variabel sistem perencanaan anggaran, partisipasi dalam penyusunan anggaran dan kejelasan sasaran anggaran mempunyai pengaruh yang signifikan terhadap kinerja manajerial.

\section{Pengujian Hipotesis II}

Dalam penelitian pengujian efek moderasi dan efek utama dilakukan dengan menggunakan analisis regresi moderasi lewat suatu metode yang disebut dengan analisis regresi berjenjang (hierarchical regression analysis). Metode ini membutuhkan dua buah persamaan regresi, yatu pertama yang hanya berisi efek-efek utama dan yang kedua berisi dengan efek-efek utama dan efek moderasi. Persaman untuk penelitian ini adalah sebagai berikut:

$$
\mathbf{Y}=\beta_{1}+\beta_{1} X_{1}+\beta_{2} X_{2}+\beta_{3} X_{3}+\beta_{4} X_{4}+\beta_{5} X_{5}+\beta_{3} X_{1}-X_{5}+\beta_{4} X_{2}-X_{5}+
$$

Tabel 5. Uji Koefisien Determinasi

Model Summary ${ }^{\mathrm{b}}$

\begin{tabular}{|l|r|r|r|r|r|}
\hline Model & $\mathrm{R}$ & R Square & $\begin{array}{c}\text { Adjusted R } \\
\text { Square }\end{array}$ & $\begin{array}{c}\text { Std. Error of } \\
\text { the Estimate }\end{array}$ & $\begin{array}{c}\text { Durbin- } \\
\text { Watson }\end{array}$ \\
\hline 1 &, $700^{\mathrm{a}}$ &, 490 &, 450 & 1,551 & 1,814 \\
\hline
\end{tabular}

a. Predictors: (Constant), INTER_4, KSA, PPA, INTER_1, PI

b. Dependent Variable: KM

Tabel 5 Uji kooefisien Determinasi diatas yang terdiri dari pengujian R, R Squre, dan Adjusted R Square dapat dijelaskan bahwa variabel pengawasan internal adalah variabel independen yang secara bersama-sama mempengaruhi kinerja manajerial, tetapi secara parsial pengawasan internal tidak mempunyai pengaruh secara signifikan terhadap kinerja manajerial. Untuk melihat efek moderasi dari variabel pengawasan internal, maka dilakukan pengujian terhadap model kedua. Hasil pengujian model kedua menunjukkan bahwa tidak ada peningkatan nilai $\mathrm{R}^{2}$ (dalam hal ini dilihat dari nilai adjusted $\mathrm{R}^{2}$ ). Justru terjadi penurunan nilai $\mathrm{R}^{2}$. Dalam model 1 nilai adjusted $\mathrm{R}^{2}=0,457$, sedangkan model 2 nilai adjusted $R^{2}=0$, 450. Hal ini menunjukkan bahwa tidak ada efek moderasi dari variabel pengawasan internal. Hal ini sejalan dengan kriteria kedua, bahwa variabel pengawasan internal tidak mempunyai efek moderasi terhadap semua variabel independen dengan tingkat signifikansi $5 \%$ Berdasarkan hal ini dapat disimpulkan bahwa variabel pengawasan internal bukan merupakan variable moderasi yang memperkuat hubungan antara sistem perencanaan anggaran, partisipasi penyusunan anggaran, skedul penyusunan anggaran dan kejelasan sasaran anggaran dengan kinerja manajerial. 
Tabel 6. Uji t untuk Kinerja Manajerial Coefficients $^{\mathrm{a}}$

\begin{tabular}{|c|c|c|c|c|c|c|}
\hline \multirow{2}{*}{\multicolumn{2}{|c|}{ Model }} & \multicolumn{2}{|c|}{$\begin{array}{c}\text { Unstandardized } \\
\text { Coefficients }\end{array}$} & \multirow{2}{*}{$\begin{array}{c}\text { Standardized } \\
\text { Coefficients } \\
\text { Beta } \\
\end{array}$} & \multirow[b]{2}{*}{$\mathrm{t}$} & \multirow[b]{2}{*}{ Sig. } \\
\hline & & B & Std. Error & & & \\
\hline \multirow[t]{6}{*}{1} & (Constant) & 7,617 & 2,438 & & 3,124 & ,003 \\
\hline & $\begin{array}{l}\text { Partisipasi Penyusunan } \\
\text { Anggaran }\end{array}$ & ,161 & , o88 & , 188 & 1,834 & , 071 \\
\hline & $\begin{array}{l}\text { Kejelasan Sasaran } \\
\text { Anggaran }\end{array}$ & ,256 & , 096 & ,353 & 2,667 & , 010 \\
\hline & Pengawasan Internal & 252 & 164 & ,281 & 1,536 & ,130 \\
\hline & INTER_1 & ,246 & ,106 &, 322 & 2,307 & ,024 \\
\hline & INTER_4 &,- 031 & , o76 &,- 052 &,- 404 & ,688 \\
\hline
\end{tabular}

a. Dependent Variable: KM

Secara parsial pengawasan internal tidak mempunyai pengaruh secara signifikan terhadap kinerja manajerial karena tingkat signifikansinya o, 130 atau kurang dari 0,05. Berdasarkan hal ini dapat disimpulkan bahwa variable pengawasan internal bukan merupakan variabel moderasi yang memperkuat hubungan antara sistem perencanaan anggaran, partisipasi penyusunan anggaran, skedul penyusunan anggaran dan kejelasan sasaran anggaran dengan kinerja manajerial.

\section{SIMPULAN}

Berdasarkan hasil analisis sebagaimana telah diuraikan sebelumnya, maka ditarik kesimpulan Hasil penelitian menunjukkan bahwa sistem perencanaan anggaran, partisipasi dalam penyusunan anggaran, kejelasan sasaran anggaran berpengaruh secara signifikan terhadap kinerja manajerial. Penelitian ini sejalan dengan hasil penelitian yang dilakukan bangun (2009) dan juga hasil penelitian yang dilakukan oleh Syafrial (2009). Sedangkan ketepatan skedul penyusunan anggaran tidak berpengaruh terhadap kinerja manajerial. Hal ini sejalan dengan hasil penelitian oleh Syafrial (2009) yang menyimpulkan bahwa Ketepatan Skedul Penyusunan anggaran tidak berpengaruh positif terhadap kinerja manajerial. Hasil penelitian menunjukkan bahwa pengawasan internal tidak dapat memoderasi pengaruh sistem perencanaan anggaran, partisipasi dalam penyusunan anggaran, skedul penyusunan anggaran dan kejelasan sasaran anggaran terhadap kinerja manajerial. Hal ini sejalan dengan dengan penelitian Bangun (2009) bawa variabel pengawasan internal tidak dapat memoderasi pengaruh partisipasi dalam penyusunan anggaran, kejelasan sasaran anggaran dan stuktur desentralisasi terhadap kinerja manajerial

\section{PUSTAKA ACUAN}

Anggraeni, Rafika. 2009. Pengaruh partisipasi anggaran dan komitmen Organisasi terhadap kinerja SKPD Pemerintahan kabupaten labuhan batu. Medan: Fakultas Ekonomi Universitas Sumatera Utara. 
Azis, Noor. 2011. Analisis Pengaruh Partisipasi Penyusunan Anggaran, Kejelasan Anggaran dan Umpan Balik terhadap Peningkatan Kinerja Manajerial melalui Kepuasan kerja dan Ketidakpastian Lingkungan sebagai Variabel Moderating. Jurnal Analisis Manajemen $\mathrm{Vol}_{5}$, No 1

Badriyah, Nurul, Sari Ria Nelly, dan Savitri Enni. 2013. Pengaruh Partisipasi Penyusunan Anggaran, Kejelasan Sasaran Anggaran, Kesulitan Sasaran Anggaran, Evaluasi Anggaran Dan Umpan Balik Anggaran Terhadap Kinerja Manajerial. Universitas Riau

Bangun. Andarias. 2009. Pengaruh partisipasi dalam penyusunan anggaran, Kejelasan sasaran anggaran dan struktur Desentralisasi terhadap kinerja manajerial SKPD dengan pengawasan internal sebagai Variabel pemoderasi (studi kasus pada Pemerintah kabupaten deli serdang. Medan: Sekolah Pasca Sarjana Universitas Sumatera Utara.

Bastian, Indra. 2006. Akuntansi Sektor Publik: Suatu Pengantar. Jakarta: Erlangga.

Dharma, Emile Setia. 2004. Pengaruh Kejelasan Sasaran Anggaran dan Sistem Pengendalian Akuntansi Terhadap Kinerja Manajerial dengan Komitmen Organisasi Sebagai Variabel Pemoderisasi pada Pemerintah Daerah, Studi Empiris pada Kabupaten dan Kota Se-Propinsi Daerah Istimewa Yogyakarta, Bali: Simposium Nasional Akuntansi VII.

Effendy, Onong Uchjana. 1989. Kamus Komunikasi.Bandung: PT.Mandar Maju.

Erwati, Misni. 2009. Pengaruh partisipasi penyusunan anggaran berbasis kinerja (ABK) terhadap kinerja kepala satuan kerja perangkat daerah (SKPD) pemerintah daerah dengan komitmen organisasi dan gaya kepemimpinan sebagai variabel moderating (survey pada aparatur pemerintah Kota Jambi). Percikan: pemberitaan ilmiah. Ikatan Keluarga Besar Universitas Jambi.

Ghozali, Imam. 2005. Aplikasi Multivariate dengan Program SPSS. Semarang: Universitas Diponegoro

Halim, Abdul. 2007. Akuntansi Sektor Publik, Akuntansi keuangan Daerah, Edisi 3, Jakarta: Salemba Empat.

Hamid, Rizky. 2011. Pengaruh Sistem Perencanaan Anggaran, Sistem Informasi Keuangan Daerah Dan Sistem Pengelolaan Keuangan Daerah di Era Otonomi Daerah Terhadap Kemampuan Daya Serap Anggaran di Pemerintahan Kota DKI Jakarta. Jakarta: Program Magister Akuntansi Universitas Trisakti.

Harahap, Sofyan Syafri. 2004. Teori Akuntansi, Edisi Revisi, Cetakan Keenam. Jakarta: PT. Raja Grafindo Persada.

Indriantoro, Nur dan Bambang Supomo. 2002. Metodologi Penelitian Bisnis. Yogyakarta: BPMP

Kenis. I. 1979. Effect of Budgetary Goal Characteristics on Managerial Attitues and Performance, The Accounting review. Vol LIV No.4 October

Mahoney, T.A. T.H.Jardee,and S.J. Carrol. 1963. "Development of Managerial Performance: A Reseach Approach”. Southwestern PublishingCo. Cincinati,Ohio.

Mardiasmo. 2001. Desentralisasi Sistem dan Desentralisasi Fiskal. Yogyakarta: Fakultas Ekonomi Universitas Gadjah Mada.

Muhlis, Syarifuddin Dan Mediaty. 2009. Pengaruh Partisipasi Penyusunan Anggaran Terhadap Kinerja Aparatur Pemerintah Da erah dengan Budaya Organisasi dan Komitmen Organisasi Sebagai Moderator (studi kasus pada pemerintah Kabupaten Barru Sul-Sel.pp.1-13.

Nafarin, M. 2004. Penganggaran Perusahaan, Edisi Revisi, Salemba Empat, Jakarta.

Nasir, Azwir; Oktari, Ranti. 2011. Pengaruh Pemanfaatan Teknologi Informasi dan Pengendalian Intern Terhadap Kinerja Instansi Pemerintah (Studi Pada Satuan Kerja Perangkat Daerah Kabupaten Kampar). Jurusan Akuntansi Fakultas Ekonomi Universitas Riau.Jurnal Ekonomi Vol 19, No 02. 
Nawawi, Hadari. 2002. Manajemen Sumber Daya Manusia Untuk Bisnis Yang Kompetitif. Yogyakarta: Gadjah Mada University Press.

Nordiawan, Deddi. 2006. Akuntansi Sektor Publik. Jakarta: Salemba Empat.

Prawirosentono.S. 1999. Manajemen Sumber Daya Manausia, Kebijakan Kinerja Karyawan. Yogyakarta: BPFE.

Ramandei, Pilipus. 2010. Karakteristik Sasaran Anggaran, Sistem Pengendalian Intern Dan Kinerja Manajerial Aparat Pemerintah Daerah. Jurnal Maksi Vol 10. No.1 Januari 2010 hal 55-73. Jayapura

Riyanto, B. 2003. Model Kontijensi Sistem Pengendalian: Integrasi dan Ekstensiuntuk Future Research. KOMPAK: Jurnal Akuntansi, Manajemen, dan Sistem Informasi FE UTY Yogyakarta. No: 9. April. 330-342

Renyowijoyo, Muindro. 2010. Akuntansi Sektor Publik Organisasi Non Laba. Jakarta: STIE TRISAKTI.

Saerang, David dan Wokas Heince. 2011. Pengaruh Kejelasan Sasaran Anggaran Terhadap Kinerja Pemerintah Pada Pemerintah Kota Tomohon. Manado: Jurnal riset Akuntansi dan AuditingMagister Akuntansi Fakultas ekonomi Unsrat, Volume 2, Nomor 1

Sagara, Yusar. 2011. Analisa Pengelolaan Keuangan Sebelum dan Setelah Ditetapkan Sebagai Satuan Kerja (satker) BLU Terhadap Peningkatan Kinerja Keuangan dan Kinerja Administrasi Studi Kasus UIN Syarif Hidayatullah Jakarta. Jakarta: Program Magister Akuntansi Universitas Trisakti.

Sardjito, Bambang dan Muthaher, Osmad. 2007. Pengaruh Partisipasi Penyusunan Anggaran Terhadap Kinerja Aparat Pemerintah Daerah: Budaya Organisasi Dan Komitmen Organisasi Sebagai Variabel Moderating. Makasar: Simposium Nasional Akuntansi X,

Stoner, James A.F. 1986. Manajemen. Jilid II.Edisi Kedua Terjemahan. Jakarta: Erlangga

Syafrial. 2009. Pengaruh Ketepatan Skedul Penyusunan Anggaran, Kejelasan Sasaran Anggaran Dan Partisipasi Penyusunan Anggaran Terhadap Kinerja Manajerial Skpd Pada Pemerintah Kabupaten Sarolangun. Medan: Sekolah Pasca Sarjana Universitas Sumatera Utara.

Suhartono, Erhmann dan Halim, Abdul. 2006. Pengaruh Kejelasan Sasaran Anggaran Terhadap Senjangan Anggaran Instansi Pemerintah Daerah Dengan Komitmen Organisasi Sebagai Pemoderasi. Padang: Simposium Nasional Akuntansi IX.

Supratiningrum dan Zulaikha, 2003. Pengaruh Total Quality Management terhadap Kinerja Manajerial dengan Sistem Pengukuran Kinerja dan Sistem Penghargaan (Reward) sebagai variabel Moderating (Studi empiris pada Hotel di Indonesia), Simposium Nasional Akuntansi VI, Oktober, Hal. 775-789.

Yuwono, Sony. 2005. Penganggaran Sektor Publik, Bayumedia Publishing, Jatim. 